\title{
Lumbo-costo-vertebral syndrome with inguinal hernia and other anomalies
}

\author{
Rajpal Singh Sisodiya, Shasanka Shekhar Panda, Simmi K Ratan
}

Paediatric Surgery, Maulana Azad Medical College,

New Delhi, India

\section{Correspondence to} Dr Rajpal Singh Sisodiya, rajpalsinghs025@gmail.com

Accepted 3 January 2017
CrossMark

To cite: Sisodiya RS, Shekhar Panda S, Ratan SK. BMJ Case Rep Published online: [please include Day Month Year] doi:10.1136/ bcr-2016-216974

\section{DESCRIPTION}

A 20 day-old full-term vaginally delivered baby boy, weighing $3.25 \mathrm{~kg}$, presented to the surgical department with deformity of spine and lower limbs, swelling in left groin and left lumbar region since birth. Antenatal ultrasound was not available. On examination, the child was active, crying well, lips were cyanosed and there was no pedal oedema. Cardiovascular examination revealed the presence of systolic murmur. Abdominal examination showed the presence of left lumbar and inguinal hernia (figure 1). Telipus equinovarus deformity was present bilaterally in lower limbs. Scoliosis of spine with concavity towards left side was present. Echocardiography showed tetralogy of Fallot. Ultrasound scan of the abdomen revealed the absence of left kidney, left lumbar and inguinal hernia. X-ray showed scoliosis, hemivertebrae of thoracic region, left rib anomalies, herniation of bowel loops in left lumbar region and left scrotum (figure 2).

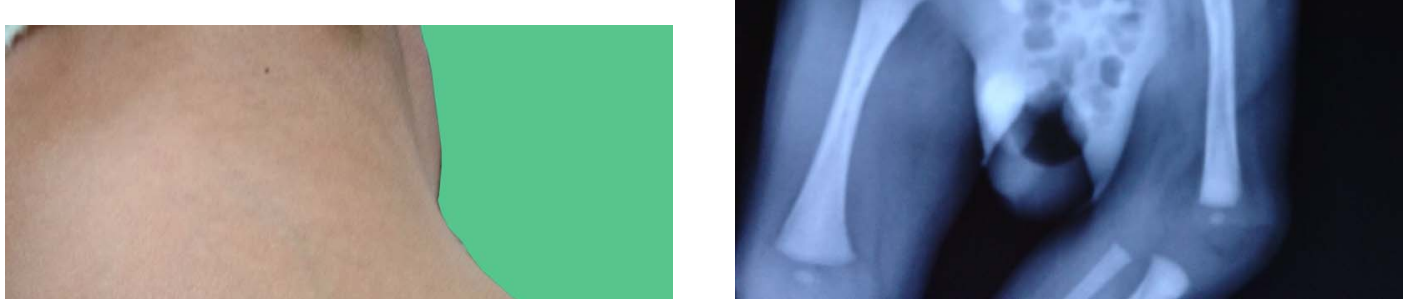

Figure 2 Costo-vertebral anomalies, scoliosis, bowel loops in lumbar and inguinal hernia sac.

\section{Learning points}

- Lumbo-costo-vertebral syndrome includes hemivertebra, congenital anomalies of ribs, anterior myelomeningocele and abdominal wall muscular hypoplasia.

- Identification of anomalies associated with lumbo-costo-vertebral syndrome should therefore direct prompt thorough evaluation for other anomalies.

- Evaluation should include radiographic studies and appropriate consultation of specialists.

Lumbo-costo-vertebral syndrome is a rare disorder comprising of vertebral, ribs and abdominal musculature anomalies along with other associated anomalies such as inguinal hernia, telipus 
equinovarus, absence of kidney, congenital heart disease and many others. ${ }^{1-3}$ It has been postulated that single somatic mutation during the third to fifth week of gestation lead to the development of this constellation of disorder. ${ }^{1}$ Lumbo-costo-vertebral syndrome with bony, cardiac and renal anomalies was found to be an associated anomaly to VACTERL syndrome. ${ }^{3}$ This case represents rare association of congenital anomalies and highlights the requirement of multidisciplinary subspecialty in management.

Contributors RSS, SSP and SKR have seen the case, advised necessary investigation, prepared the manuscript and edited. RSS will be guarantor for this manuscript.
Competing interests None declared.

\section{Patient consent Obtained.}

Provenance and peer review Not commissioned; externally peer reviewed.

\section{REFERENCES}

1 Krishnamurthy S, Kapoor S. An incomplete form of lumbocostovertebral syndrome in association with atrial septal defect, arthrogryposis and clubfeet. Indian J Pediatr 2009:76:411-13.

2 Gupta L, Mala TA, Gupta R, et al. Lumbo-costo-vertebral syndrome with congenital lumbar hernia. APSP J Case Rep 2014;5:5.

3 Harris K, Dorn C, Bloom B. Lumbocostovertebral syndrome with associated VACTERL anomalad: a neonatal case report. J Perinatol 2009;29:826-7.

Copyright 2017 BMJ Publishing Group. All rights reserved. For permission to reuse any of this content visit http://group.bmj.com/group/rights-licensing/permissions.

BMJ Case Report Fellows may re-use this article for personal use and teaching without any further permission.

Become a Fellow of BMJ Case Reports today and you can:

- Submit as many cases as you like

- Enjoy fast sympathetic peer review and rapid publication of accepted articles

- Access all the published articles

- Re-use any of the published material for personal use and teaching without further permission

For information on Institutional Fellowships contact consortiasales@bmjgroup.com

Visit casereports.bmj.com for more articles like this and to become a Fellow 